THE DARWIN READER. Ed. by Marston Bates and P. S. Humphrey. Macmillan, London. 1957. Pp. 481.30 s.

An anthology of Darwin's writings combined with a valuable bibliography and notes. Its special characteristics are that it abridges the enlarged sixth edition of the Origin of Species (1 872). It includes the I $85^{8}$ correspondence but it omits any extracts from the four books which include his experimental and forward-looking work on plants. Perhaps intentionally it omits reference to Darwin's outstanding mistakes. And it omits his clearest statements on human heredity (in Animals and Plants) possibly because the editors think they are mistakes. It includes only one of his thousand or two published letters and it omits reference to Keith's Darwin Re-valued (London, 1954) and the anonymous Autobiography (New York, 1950). There is a good index which however refers the reader to evolution where Darwin did not use the word (in the Origin) and not where he did use it (in the Descent of Man).

For all its shortcomings we must be grateful to the editors and publishers for a well-produced and much needed book.

C. D. D.

\title{
SHORT REVIEWS
}

EFFECT OF RADIATION ON HUMAN HEREDITY : Report of a Study Group convened by the World Health Organisation together with Papers presented by Various Members of the Group. Geneva. 1957. Pp. 168. $£ 1$.

An account by twelve authorities of the data that will have to be considered and the methods that will have to be used in attempting to discover the genetic effects of irradiation on human populations and to determine whether these effects are advantageous or disadvantageous to the populations that are exposed to radiation.

THE HUMAN SUM. Ed. by C. H. Rolph. Heinemann, London. 1957. Pp. 232. 18 s.

An account of population control and family planning chiefly in England, by ten authors, delightfully decorated by ironical cartoons. Genetic aspects are omitted. There is an appendix attempting to reconcile social needs with the doctrine of the Church of England and vice versa.

BLOOD ROYAL. I. Moncreiffe and D. Pottinger. Nelson, London. 1956. Pp. 64. 12s.6d.

Under the disguise of a brilliantly illustrated children's book of kings this learned work on the European royal families explains their racial origins and erratic breeding system with its unexampled alternation of inbreeding and outbreeding and of course its unexampled documentation.

MAN'S JOURNEY THROUGH TIME. L. S. Palmer. Hutchinson, London. 1957. Pp. 184. 30 s.

An attempt to link the development of man recorded by fossil remains of bones with that recorded by history and pre-history. The attempt, which is hazardous in any case, is made more so by the author's neglect of the vast evidence of present variation.

Addendum : Theoretical Genetics by R. B. Goldschmidt, reviewed in Heredity, Io, p. 434, is issued in Britain by the Cambridge University Press. 